\title{
進行性尿路上皮癌に対する Methotrexate/5-Fluorouracil
}

\section{時間差投与，Doxorubicin，Cisplatinを用いた}

\author{
多剂併用化学療法の効果
}

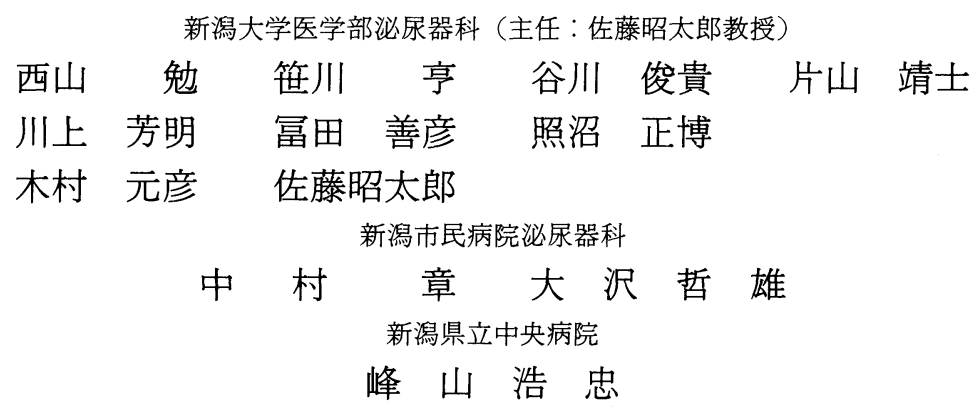

\section{SEQUENTIAL METHOTREXATE AND 5-FLUOROURACIL, DOXORUBICIN, AND CISPLATIN FOR ADVANCED UROTHELIAL CANCER}

\author{
Tsutomu Nishiyama, Toru Sasagawa, Toshiki Tanikawa, Yasushi Katayama, \\ Yoshiaki Kawakami, Yoshihiko Tomita, Masahiro Terunuma, \\ Motohiko Kimura and Shotaro Sato \\ Department of Urology, Niigata University School of Medicine, Niigata, Japan \\ (Director: Prof. Shotaro Sato) \\ Tetsuo Osawa and Sho Nakamura \\ Section of Urology, Niigata Shimin Hospital \\ Hirotada Mineyama \\ Section of Urology, Niigata Central Hospital
}

Twenty cases (fourteen males, six females, mean age 66.0) with locally advanced (T2-4 N0, M0, $\mathrm{n}=9$ ) or metastatic (N2-3 or $\mathrm{M} 1, \mathrm{n}=11$ ) urothelial cancer were treated sequentially with methotrexate (MTX) and 5-fluorouracil (5-FU), Doxorubicin (ADM), and cisplatin (CDDP) since August, 1988. Primary tumors were in the bladder in fifteen patients and in the renal pelvis or ureter in five cases. Histological findings were adenocarcinoma in one and transitional cell carcinoma in the other cases. Histological grades were grade 2 in four, grade 3 in fifteen, poorly differentiated adenocarcinoma in one. Seven patients were treated by neoadjuvant chemotherapy. Three were treated for recurrent lesions. Ten were treated for the unresectable disease. The patients received one to four cycles of this regimen (average: 2.8 cycles). Complete clinical response was observed in seven of twenty patients (35\%) with bidimentionally measurable indicator lesions. Seven patients (35\%) had a partial clinical response. Significant tumor regression was noted in fourteen of twenty patients (70\%) in total, in eight of ten $(80 \%)$ treated with full dose chemotherapy. The group of full dose chemotherapy showed an improved trend in survival rate as compared with the group treated by $80 \%$ and less dose chemotherapy. Toxicity was relatively mild, with anemia, leukopenia, thrombocytopenia, and no drug related death. The results suggest that the combined chemotherapy with sequential MTX and 5-FU, $\mathrm{ADM}$, and CDDP is remarkably effective on advanced urothelial cancer.

Key words: advanced urothelial cancer, combination chemotherapy regimen, biochemical modulation 
要旨：進行尿路上皮癌患者で評価対象病変のある患者20例を対象に Methotrexate (MTX)/5-Fluorouracil $(5 \mathrm{Fu})$ 時間差投与, Doxorubicin (ADM), Cisplatin (CDDP) 多剂併用化学療法 (MFAP 療法) を行った。症例により抗癌剤投与終了後から Dypyridamol の投与を行った。性別は男14例, 女 6 例で年 歯令は39 86歳で, 平均 66.0 歳であった。原発腫瘍は膀胱癌が 15 例，腎孟尿管癌が 5 例であった。組織型 は腺癌が 1 例で, 他の 19 例は移行上皮癌であった。組織学的悪性度は移行上皮癌では $\mathrm{G} 2$ が 4 例, G3が 15 例であった，腺癌は低分化型腺癌であった。進行膀腃癌の術前化学療法として行われたものが 7 例, 原 発巣摘除後の再発が 3 例，転移巣を有する症例または手術不能症例が 10 例であった。施行回数は 1 回か ら 4 回で平均 2.8 回であった. 治療成績は奏功度では CR 7 例 $35 \%, \mathrm{PR} 7$ 例 $35 \%, \mathrm{NC} 6$ 例 $30 \%$ であった。 PR 以上の奏功率は70\%であった. 投与量を減量しなかった症例では奏効率 $80 \%$ と高率であった。臨床的 効果と病理組織学的効果とは相関を認めた。生存率では投与量を減量しなかった群で生存期間が延長す る傾向が認められた。 副作用は貧血, 白血球減少, 血小板減少, 悪心呕吐, 下浰, 脱毛, 呼吸器障害, 口内炎, 耳鳴, 難聴などであった。 MFAP 療法は進行性尿路上皮癌に対していますで報告されている療 法以上に有用な化学療法と思われる。

キーワード：進行性尿路上皮癌, 多剂併用化学療法, biochemical modulation

\section{緒言}

進行性尿路上皮癌に対する化学療法は Cisplatinの 登場以来, これを中心とする多剤併用療法が考案され, M-VAC 療法など有効な多剂併用療法が報告され，そ の有用性が評価されつつある1). 近年, Biochemical modulation といら概念から抗癌剂等の併用に上る生 化学的な効果の修飾が研究されてきており, Methotrexate (MTX) と5-Fluorouracil (5FU) 時間差投 与法などが考案され, 臨床に応用されはじめている21. このような考光を基に, 我々は1988年 8 月から進行尿 路上皮癌患者を対象に MTX と $5 \mathrm{FU}$ 時間差投与法を 取り入れ，さらにDoxorubicin (ADM), Cisplatin (CDDP) を用いた多剤併用化学療法 (MFAP 療法)を 考案し, 行っている. 今回, 現在までに MFAP 療法を 施行された進行性尿路上皮癌症例の結果を報告する。

\section{対象ならびに方法}

1988年 8 月から新潟大学医学部泌尿器科, 新潟市民 病院泌尿器科, 新潟県立中央病院泌尿器科に扔いて加 療された転移または浸潤を認める進行尿路上皮癌で, 評価対象病変のある患者20例であった(表 1 ). 性別は 男14例, 女 6 例であった. 年齢は39 86歳で, 平均 66.0 歳であった. 原発腫瘍は膀胱癌が15例, 腎孟尿管癌が 5 例であった。進行性膀胱癌で病変が膀胱局所に限局 している症例に対する術前化学療法として行われたも のは 7 例で, これらの症例はすべて施行前に経尿道的 膀胱腫瘍生検が行われたが, 積極的な腫瘍切除術は行 わなかった. 膀胼全摘除術後の再発症例に対する化学 療法として行われたものは 3 例, 転移巣を有する症例 または手術不能症例に対する化学療法として行われた
ものが10例であった，組織型は腺癌が 1 例で，他の 19 例は移行上皮癌であった。組織学的悪性度は移行上皮 癌では $\mathrm{G} 2$ が 4 例で $\mathrm{G} 3$ が15例であった．腺癌は低分化 型腺癌であった。進行度は $\mathrm{T}$ 分類で $\mathrm{T} 2$ が 2 例, $\mathrm{T} 3$ 3゙ 6 例, T 4 が 9 例, 原発巣摘除術後が 3 例であった. N 分類で $\mathrm{N} 0$ が 12 例, N2が 2 例, N3が 6 例, M 分類で M0 が16例, M1が 4 例であった。転移部位は肺が 2 例, 肺十 肝が 1 例, 骨が 1 例であった. Performance status (PS) は PS 0 が10例, PS1が 8 例, PS2が 1 例, PS 3 が 1 例であった。抗癌剤の投与方法（図 1 ）は 4 週間を 1 コースとし，第 1 日，第 15 日に MTX/5FU 時間差投 与法として MTX $200 \mathrm{mg} / \mathrm{m}^{2}$ を投与，その 3 時間後に $5 \mathrm{FU} 600 \mathrm{mg} / \mathrm{m}^{2}$ を投与した。 MTX 投与 24 時間後から ロイコボリン $15 \mathrm{mg}$ を 6 時間間隔で 4 回投与した。第 8 日に $\mathrm{ADM} 40 \mathrm{mg} / \mathrm{m}^{2}, \mathrm{CDDP} 100 \mathrm{mg} / \mathrm{m}^{2}$ の投与を行 なった. Dipyridamole(DP) 投与症例は DP 300mg を $5 \mathrm{FU}, \mathrm{CDDP}$ 投与終了後 6 時間かけて投与した。患者 の状態, 臨床検査データを考慮し抗癌剂の投与量, 投 与間隔は適宜変更した。施行回数は 3 コースを目標に 症例により適宜変更した。 以前に術後補助化学療法と して MFAP 療法を 2 コース行い，既にADMを使用 した既往のある 1 例と心疾患 (WPW 症候群) を合併 していた 1 例に対して ADMに替えて同量の Epirubicin（EpiADM）を使用した。をた MFAP 療法 1 コース終了後に耳鳴, 難聴が強く出現した症例に対し て2コース目からCDDPに変えて Carboplatin 450 $\mathrm{mg} / \mathrm{m}^{2}$ を使用した。臨床効果判定は日本癌治療学会固 形がん化学療法直接効果判定基準 ${ }^{3}$, 泌尿器科. 病理膀 脱癌取扱(規約), 泌尿器科. 病理腎孟. 尿管癌取扱い 
表 1 対象症例

\begin{tabular}{|c|c|c|c|c|c|c|c|c|c|c|c|c|}
\hline \multicolumn{2}{|c|}{ 症例 } & 年齢. 性 & PS & 原発巣 & 組織型 & 異型度 & $\mathrm{T}$ & $\mathrm{N}$ & M & 前治療 & 評価可能病変 & 合併症 \\
\hline 1 & $\mathrm{TH}$ & 60. M & 1 & 膀胱 & TCC & 3 & 4 & 0 & 0 & なし & 膀胱 & \\
\hline 2 & O I & 66. $\mathrm{M}$ & 0 & 膀脱 & TCC & 3 & 3 & 0 & 0 & なし & 膀胱 & \\
\hline 3 & SW & 59. W & 0 & 膀胱 & TCC & 3 & 4 & 0 & 0 & なし & 膀胱 & \\
\hline 4 & M I & 60. M & 0 & 膀胱 & $\mathrm{AC}$ & por & 3 & 0 & 0 & なし & 膀胼 & WPW 症候群 \\
\hline 5 & Y K & 86. $\mathrm{M}$ & 0 & 膀脱 & TCC & 3 & 3 & 0 & 0 & なし & 膀胱 & \\
\hline 6 & S K & 78. W & 0 & 膀胼 & TCC & 2 & 2 & 0 & 0 & なし & 膀胱 & \\
\hline 7 & MK & 66. M & 0 & 膀脱 & TCC & 2 & 4 & 0 & 0 & なし & 膀胼 & \\
\hline 8 & $\mathrm{TH}$ & 73. $\mathrm{M}$ & 3 & 膀胱 & TCC & 3 & 3 & 0 & 0 & なし & 膀脱 & 资髄小脳変性症 \\
\hline 9 & C I & 65. M & 0 & 腎盂 & TCC & 3 & 4 & 0 & 0 & $\begin{array}{l}\text { 右腎尿管 } \\
\text { 全摘除術 }\end{array}$ & 膀胼前立腺 & \\
\hline 10 & S S & 59. $\mathrm{M}$ & 0 & 膀胱 & TCC & 3 & 2 & 3 & 0 & なし & $\begin{array}{l}\text { 膀脱 } \\
\text { リソパ節 }\end{array}$ & \\
\hline 11 & H I & 63. $\mathrm{M}$ & 1 & $\begin{array}{l}\text { 腎孟 } \\
\text { 管 }\end{array}$ & TCC & 3 & 4 & 3 & 0 & 右腎摘除術 & $\begin{array}{l}\text { 尿管 } \\
\text { リンパ節 }\end{array}$ & \\
\hline 12 & $\mathrm{KM}$ & 69. $\mathrm{M}$ & 1 & 腎孟 & TCC & 3 & 4 & 3 & 0 & なし & $\begin{array}{l}\text { 腎孟 } \\
\text { リンパ節 }\end{array}$ & \\
\hline 13 & YM & 53. $\mathrm{M}$ & 0 & $\begin{array}{l}\text { 㹂需 } \\
\text { 管 }\end{array}$ & TCC & 3 & 4 & 3 & 0 & なし & $\begin{array}{l}\text { 腎孟尿管 } \\
\text { リンパ節 }\end{array}$ & 特発性血小板減少症 \\
\hline 14 & SW & 39. $\mathrm{M}$ & 1 & 尿管 & TCC & 3 & 4 & 3 & 0 & なし & $\begin{array}{l}\text { 尿管 } \\
\text { リソパ節 }\end{array}$ & \\
\hline 15 & $\mathrm{KH}$ & 74. W & 1 & 膀胼 & TCC & 2 & 3 & 0 & 1 & なし & $\begin{array}{l}\text { 膀胱 } \\
\text { 骨 }\end{array}$ & \\
\hline 16 & S Y & 68. M & 0 & 膀脱 & TCC & 2 & 3 & 0 & 1 & & $\begin{array}{l}\text { 膀胱 } \\
\text { 肺 }\end{array}$ & \\
\hline 17 & K S & 70. W & 0 & $\begin{array}{l}\text { 腎霡管 } \\
\end{array}$ & TCC & 3 & 4 & 3 & 1 & なし & $\begin{array}{l}\text { 腎孟尿管 } \\
\text { 管ど節 } \\
\text { 肺 }\end{array}$ & \\
\hline 18 & TY & 73. $\mathrm{M}$ & 0 & 膀胱 & TCC & 3 & & 2 & 0 & 膀胼全摘除術 & リンパ節 & \\
\hline 19 & H I & 68. W & 2 & 膀胱 & TCC & 3 & & 2 & 0 & 膀胼全摘除術 & リンパ節 & \\
\hline 20 & $\mathrm{ST}$ & 70. W & 1 & 膀脱 & TCC & 2 & & 0 & 1 & $\begin{array}{l}\text { 膀胼全摘除術 } \\
\text { MFAP } \\
2 \text { コース }\end{array}$ & $\begin{array}{l}\text { 肝 } \\
\text { 肺 }\end{array}$ & \\
\hline
\end{tabular}

症例 $1 \sim 7$ : 術前化学療法群, 症例 $8 \sim 17$ : 転移を有する症例または手術不能症例, 症例 $18 \sim 20$ : 再発症例 症例 8 は術前化学療法の予定で施行されたが，本人家人の手術の同意が得られず，施行後経過観察とされた

図 1 MFAP 療法プロトュール

\begin{tabular}{l|c|c|c}
\hline \multirow{2}{*}{ 投与薬剤 } & \multicolumn{3}{|c}{ 投与日 } \\
\cline { 2 - 4 } & 第 1日 & 第 8 日 & 第 15 日 \\
\hline MTX* $^{*}$ & $200 / \mathrm{m}^{2}$ & & $200 / \mathrm{m}^{2}$ \\
$5 \mathrm{FU}^{*}$ & $600 / \mathrm{m}^{2}$ & & $600 / \mathrm{m}^{2}$ \\
$\mathrm{ADM}$ & & $40 / \mathrm{m}^{2}$ & \\
$\mathrm{CDDP}$ & & $100 / \mathrm{m}^{2}$ & \\
\hline
\end{tabular}

MTX : Methotrexate, 5FU : 5-Fluorouracil, ADM : Doxorubicin, CDDP : Cisplatin

*: MTX は 1 時間かけて投与し, MTX の投与終了 3 時間後 に $5 \mathrm{FU}$ を 1 時間かけて投与する。

$\mathrm{MTX}$ 投与 24 時間後からロイコボリン $15 \mathrm{mg}$ を 6 時間間隔で 4 回投与する.

Dipyridamole (DP) 投与症例は $5 \mathrm{FU}, \mathrm{CDDP}$ 投与終了後か ら DP300mg を6 時間かけて投与する
規約)に準じて行った. 病理組織学的効果判定は MFAP 療法に引き続き膀胱全摘除術, 腎尿管全摘除術 が施行された 7 例の手術標本に対して泌尿器科. 病理 腎盂. 尿管癌取扱い規約, 組織学的治療効果判定基準 に準じて行った ${ }^{5)}$. 生存率は Kaplan-Meier 法で求め, 生存率の検定は Generalized Wilcoxon 法で行った。

\section{結 果}

1）臨床効果（表 2)：施行回数は 1 回から 4 回で平 均2.8回であった。抗癌剤投与用量は $100 \% か ゙ 10$ 例, $80 \%$ 以下が10例であった。 DP 投与例は 10 例，DP 非投与例 が10例であった. 治療成績は奏功度では CR 7 例 $35 \%$ ， PR 7 例 $35 \%$, NC 6 例 $30 \%$ であった。 PR 以上の奏功 率は $70 \%$ あったた。抗癌剤の投与用量による奏功率で は投与量 $80 \%$ 以下では CR 3 例 $30 \%$ ，PR 3 例 $30 \%$, NC 4 例 $40 \%$ であったが，投与量が $100 \%$ の症例では 
表 2 MFAP 療法施行症例の結果

\begin{tabular}{|c|c|c|c|c|c|c|c|c|c|}
\hline 症例 & 施行回数 & 変更薬剂 & DP 使用 & $\begin{array}{c}\text { 投与量 } \\
(\%)\end{array}$ & 臨床効果 & $\begin{array}{l}\text { 評価可能 } \\
\text { 病変別効果 }\end{array}$ & $\begin{array}{l}\text { 組織学 } \\
\text { 的効果 }\end{array}$ & 施行後手術 & 臨床経過(力月) \\
\hline 1 & 3 & なし & - & 75 & $\mathrm{NC}$ & 膀胱 & Ef. 1a & 膀胼全摘除術 & 3他因死 \\
\hline 2 & 3 & なし & + & 100 & PR & 膀胱 & & TUR-BT & 14他因死 \\
\hline 3 & 3 & なし & + & 100 & PR & 膀胱 & Ef. $1 \mathrm{~b}$ & 膀胼全摘除術 & 15癌なし生存 \\
\hline 4 & 2 & EpiADM & + & 100 & CR & 膀胱 & & 生検 & 13生存(再発後膀胱全摘) \\
\hline 5 & 1 & なし & - & 65 & CR & 膀胱 & & & 33癌死 \\
\hline 6 & 2 & なし & - & 80 & PR & 膀腃 & & TUR-BT & 28癌なし生存 \\
\hline 7 & 3 & なし & - & 70 & $\mathrm{NC}$ & 膀胱 & Ef. 1a & 膀朕全摘除術 & 8癌死 \\
\hline 8 & 4 & なし & - & 80 & PR & 膀脱 & & & 27 癌死 \\
\hline 9 & 3 & なし & - & 80 & $\mathrm{NC}$ & 膀腅前立腺 & & & 18 癌死 \\
\hline 10 & 3 & なし & - & 100 & PR & $\begin{array}{ll}\text { 膀胱 } & \text { PR } \\
\text { 節 }\end{array}$ & Ef. 1a & 膀胼全摘除術 & 7 癌死 \\
\hline 11 & 3 & なし & - & 80 & $\mathrm{NC}$ & $\begin{array}{ll}\text { 尿管 } & \mathrm{NC} \\
\text { 少 パ節 } & \mathrm{NC}\end{array}$ & & & 7癌死 \\
\hline 12 & 3 & なし & + & 100 & $\mathrm{NC}$ & $\begin{array}{ll}\text { 腎孟 } & \mathrm{NC} \\
\text { 節 } & \mathrm{NC}\end{array}$ & & & 11癌死 \\
\hline 13 & 2 & なし & + & 100 & PR & $\begin{array}{ll}\text { 腎孟 } & \text { PR } \\
\text { リハ節 }\end{array}$ & Ef. $1 b$ & 腎尿管全摘除術 & 15癌あり生存 \\
\hline 14 & 3 & CBDCA & + & 100 & $\mathrm{CR}$ & 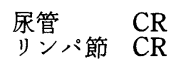 & Ef. 3 & 腎尿管全摘除術 & 8癌なし生存 \\
\hline 15 & 3 & なし & - & 75 & PR & $\begin{array}{ll}\text { 膀胱 } & \mathrm{PR} \\
\text { 号 } & \mathrm{NC}\end{array}$ & & & 7癌死 \\
\hline 16 & 3 & なし & + & 100 & CR & $\begin{array}{ll}\text { 膀胱 } & \mathrm{CR} \\
\mathrm{CR}\end{array}$ & & 生検 & 6癌なし生存 \\
\hline 17 & 3 & なし & + & 100 & $\mathrm{CR}$ & $\begin{array}{ll}\text { 腎孟尿管 } & \mathrm{CR} \\
\text { 肺莭 } & \mathrm{CR} \\
\text { 肺 } & \mathrm{CR}\end{array}$ & Ef. 2 & 腎尿管全摘除術 & 13 癌死 \\
\hline 18 & 3 & なし & - & 75 & $\mathrm{CR}$ & リンパ節 CR & & 生検 & 13癌死 \\
\hline 19 & 3 & なし & + & 80 & $\mathrm{CR}$ & リンパ節 CR & & & 22癌なし生存 \\
\hline 20 & 3 & EpiADM & + & 100 & $\mathrm{NC}$ & $\begin{array}{ll}\text { 胙 } & \mathrm{NC} \\
\text { 肺 } & \mathrm{NC}\end{array}$ & & & 12癌有り生存 \\
\hline
\end{tabular}

CR が 4 例40\%, PR が 4 例40\%, NC が 2 例20\%で あった。 DP 投与例では CR 5 例 $50 \%$, PR 3 例 $30 \%$, NC 2 例 $20 \%$ であった。術前化学療法として行われた 7 例は化学療法施行前すべて最大径 $5 \mathrm{~cm}$ 以上の単発 または多発腫瘍であったが，奏功例は 6 例で，その内 2 例で $\mathrm{CR}$ となり，2 例で画像診断上腫瘍を指摘でき ず，膀胼鏡で確認でき，同部分を経尿道的に切除し， 癌なし状態となった。計 4 例で膀脱を温存できた。転 移巣を有する症例または手術不能症例 10 例中 4 例で施 行後病巣の縮小ないし消失により根治術が施行され た。また症例16は初診時肺転移の存在していた症例で 施行後原発巣ならびに転移巣も消失し, 膀胱を温存で きた。再発例 3 例中リンパ節転移症例の 2 例はCR が 得られ，らち 1 例は 22 力経過した現在癌なし生存中 である。

2) 臓器別効果（表 2)：原発巣である膀胼では12例 中 3 例で CR, 6 例で PR, 奏功率 $75 \%$ で, 腎孟尿管で は 5 例中 2 例で $\mathrm{CR}, 1$ 例で $\mathrm{PR}$ で奏功率 $60 \%$ であっ
た。リンパ節転移巣では 8 例中 4 例で $\mathrm{CR}, 2$ 例で $\mathrm{PR}$ で奏功率 $75 \%$ であった。肺転移巣では 3 例中 2 例で CR となったが, 骨, 肝転移巣では奏功を示したものは なかった。

3）病理組織学的効果判定（表 2)：MFAP 療法施行 後膀胼全摘除術, 腎尿管全摘除術を受けた 7 例に対し て病理組織学的効果判定を行ったが, 臨床効果判定の $\mathrm{CR}$ 症例の 1 例は Ef. 3, 1 例は Ef. 2, PR 症例では 2 例が Ef. 1b， 1 例が Ef. 1a，NC 症例 2 例は Ef. 1a で あった。症例が少ないが, 臨床効果と病理組織学的効 果の間に相関を認めた。

4）生存率：全症例の平均生存期間は 20.6 力 あった。投与量 $80 \%$ 以下の症例では平均生存期間は 19.7 月で投与量 $100 \%$ 症例では 24.3 月であった。 両群間の生存率に有意な差は認めなかったが, 投与量 100\%群に生存期間が延長する傾向を認めた（図 2 ）.

5）副作用（表 3 ）：副作用は唃血, 白血球减少, 血 小板減少, 悪心呕吐, 下峲, 脱毛, 呼吸器障害, 口内 
図 2 投与 $100 \%$ 群と投与 $80 \%$ 以下群の KaplanMeier 生存曲線

両群に生存率の有意の差を認めなかった。

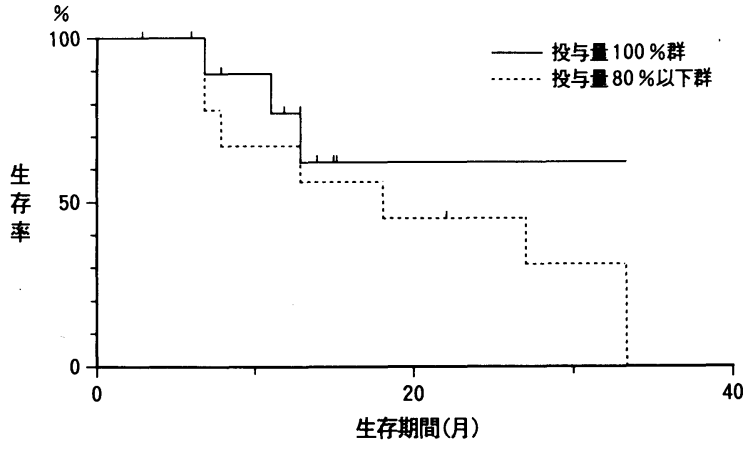

表 3 副作用

\begin{tabular}{c|r|r|r|r|r|r|r|r}
\hline Grade & 血色素 & 白血球 & 血小板 & $\begin{array}{c}\text { 覀心 } \\
\text { 呕吐 }\end{array}$ & 下洞 & 脱毛呼吸器 & 口内炎 \\
\hline 1 & 3 例 & 1 例 & 3 例 & 8 例 & 4 例 & 7 例 & & 8 例 \\
2 & 5 例 & 4 例 & 5 例 & 5 例 & & 7 例 & 1 例 & \\
3 & 10 例 & 6 例 & 4 例 & 1 例 & & 1 例 & & 1 例 \\
4 & & 7 例 & 2 例 & & & & & \\
\hline
\end{tabular}

その他：耳鳴難聴 1 例

炎, 耳鳴, 難聴などであった。投与量100\%症例では強 い骨髄抑制が認められ dose limiting factor と考兄ら れたが，施行回数の増加による副作用の程度増強は認 められなかった。

\section{考 察}

進行性尿路上皮癌は CDDP の登場以来, CDDP を中 心とした有効な多剤併用化学療法が報告され，治癒可 能な癌になりつつある1). 進行尿路上皮癌をはじめ癌 化学療法の最大の難関は癌細胞の薬剤耐性にある。こ の問題の克服のためには，尿路上皮癌に有効でかつ交 差耐性のない薬剤を組み合わせて，できるだけ短い投 与間隔で投与する必要がある ${ }^{6)}$. 現在進行性尿路上皮 癌にもっとも有効であるとされている M-VAC 療法 の regimen では交差耐性があるとされている ADM と Vinblastine が組み合わされて拉り，多剂併用化学 療法の regimen としては問題が残る7). 近年, effector となる抗癌剤の薬理動態を他の薬剂, modulatorに よって修飾することにより，抗腫瘍効果を高めたり， 副作用を軽減したりして，化学療法係数を大きくし， それによって効果を増強させることを狙ったbiochemical modulation といら概念が多剤併用療法に打 いて考慮されるようになってきた2)．MTX/5FU 時間
差療法はこのような理論を基に開発された投与法で, 腺癌などでその有用性が報告されている8)．MTX と5 FU の有効な投与間隔は組織型により異なるとされて いるが，我々のプロトコールでは投与間隔を 3 時間と した ${ }^{9}$. 最近, 抗癌剂以外の modulator としてDP の効 果が注目され，5FU，ADM，MTX，CDDPに対する 効果増強作用が報告されている ${ }^{10) ~ 13)}$. 今回, 我々が考 案したプロトコールは膀胱癌に対して単剂での効果が 認められている薬剤の中から CDDP, ADM, MTX, $5 \mathrm{FU}$ を選び，また MTX と $5 \mathrm{FU}$ に関しては MTX $/ 5$ $\mathrm{Fu}$ 時間差療法の投与方法を取り入れたもので, 1988年 8 月から実施してきた。 PR 以上の奏功率は $70 \%$ と M-VAC 療法の報告と同程度以上の結果が得られた。 投与量を減量しなかった症例での奏功率は $80 \%$ と高い ものであった．生存率でみても投与量を減量しなかっ た群に生存期間が延長する傾向を認めた。DPについ ては抗癌剤に対するなんらかの効果増強が得られてい るものと思われるが，その効果に対しては他の要素を 一定にした検討が今後必要であると思われる，臟器別 効果では原発巣, リンパ節転移巣, 肺転移巣に奏効率 が高かったが，骨，肝転移巣には奏功を示さなかった。 今後, これらの部位への投与経路等の治療法の工夫が 必要であると思われた。進行膀胼癌症例で以前は膀脱 全摘除術の適応となった 7 例中 4 例で術前化学療法を することにより膀胱を温存できた。 また, MFAP 療法 の組織学的効果は臨床効果と相関を示したが，特に CR 1 例で pCR，Ef. 3が得られたこと，また肺転移の 存在していた 1 例では本療法施行後原発巣ならびに転 移巣も消失し，膀胱を温存できたことは，今後尿路上 皮癌に颃いても精巣腫瘍と同様な集学的治療体系を考 慮していく必要があるものとおもわれる。しかし, 観 察期間が短いにもかかわらず, 癌なし状態を得られた 症例中かなりの部分がその後再発していることは癌な し状態が得られた後の化学療法の追加など強化療法や 維持療法を考慮する必要が考兄られる。副作用は骨䯣 抑制がやや強いものの十分臨床に耐光得るものであっ た。投与量を減量した症例は初期のものであり，骨䯣 抑制がみられる時期に病室をセミクリーンにし，注意 深い患者管理をすることによりほとんどの症例で $100 \%$ 投与が可能である. 今後 colony-stimulating factorの登場により抗癌剂の dose-intensity が期待でき， MFAP 療法もさらに有効な療法になり得るものと思 われる(14). 
結 語

1. 進行尿路上皮癌 20 例に $\mathrm{MTX} / 5 \mathrm{FU}$ 時間差投与, $\mathrm{ADM}, \mathrm{CDDP}$ 多剂併用化学療法を行い, その臨床的検 討, 病理組織学的検討を行った。

2. 奏効率 (CR+PR)は70\%であった。投与量 $100 \%$ の症例では奏効率 $80 \%$ と高率であった。

3. 臓器別効果では原発巣, リンパ節転移巣, 肺転移 巣に奏効率が高かったが，肝，骨転移巣には奏効例は みられなかった。

4. 進行膀脱癌症例に対して術前化学療法をするこ とにより 7 例中 4 例で膀胱温存が可能であった。

5. 臨床的効果と病理組織学的効果とは相関を認め た.

6. 生存率では投与量を減量しなかった群で生存期 間が延長する傾向が認められた。

7. 副作用では骨䯣抑制を比較的強く認め, dose limiting factor と思われた。

\section{文献}

1) Chun, H.G. and Dorr, F.A.: Systemic Chemotherapy of Transitional Cell Carcinoma of the Urothelium. Cancer Chemotherapy: Concepts, Clinical Investigations and Therapeutic Advances, p. 151-174, Kluwer Academic Publishers, Boston, 1988.

2) Bertino, J.R., Mini, E. and Fernandes, D.J. : Sequential methotrexate and 5-F luorouracil: Mechanisms of Synergy. Semin. Oncol., 10, 2-5, 1983.

3）日本癌治療学会：日本癌治療学会固形がん化学療 法効果判定基準. 日癌治療会誌，21，929-942, 1986.

4) 日本泌尿器科学会, 日本病理学会編: 泌尿器科. 病 理膀脱癌取扱い規約, 第 1 版, 金原出版, 東京, 1980.

5) 日本泌尿器科学会, 日本病理学会編：泌尿器科, 病 理腎孟. 尿管癌取扱い規約, 第 1 版, 金原出版, 東 京, 1990 .

6）古江 尚, 大田和雄, 田口鐵男, 阱井谷久暢, 藤田 浩, 塚越 茂: 多剤併用療法に上る効果の増強。癌 化学療法の基礎之臨床, 第 4 版, p. 272-310, 癌 之化学療法社, 東京, 1986 .
7) Key, S. and Merry, S.: Tumor cell resistance to anthracyclines-A review. Cancer Chemother. Pharmacol., 14, 96-103, 1985.

8) The Nordic Gastrointestinal Tumor Adjuvant Therapy Group: Superiority of sequential methotrexate, fluorouracil, and leucovorin to fluorouracil alone in advanced symptomatic colorectal carcinoma: A randomized trial. J. Clin. Oncol., 7, 1437-1446, 1989.

9) Marsh, J.C., Bertino, J.R., Katz, K.H., Davis, C. A., Durivage, H.J., Rome, L.S., Richards, F. II, Capizzi, R.L., Farber, L.R., Pasquale, D.N., Stuart, R., Koletsky, A.J., Makuch, R. and O' Hollaren, K.: The influence of drug interval on the effect of Methotrexate and fluorouracil in treatment of advanced cololectal cancer. J. Clin. Oncol., 9, 371-380, 1991.

10) Grem, J.L. and Fisher, P.H.: Enhancement of 5-fluorouracil's anticancer activity by dipyridamole. Pharmac. Ther., 40, 349-371, 1989.

11) Kusumoto, H., Maehara, Y., Anai, H., Kusumoto, T. and Sugimachi, K. : Potentiation of adriamycin cytotoxicity by dipyridamole against HeLa cells in vitro and sarcoma 180 cells in vivo. Cancer Res., 48, 1208-1212, 1989.

12) Nelson, J.A. and Drake, S.: Potentiation of methotrexate toxicity by dipyridamole. Cancer Res., 44, 2493-2496, 1984.

13) Keane, T.E., Rosner, G., Donaldson, J.T., Norwood, D.L., Poulton, S.H. and Walther, P.J.: Dipyridamole-cisplatin potentiation: Enhancer in vivo cytotoxicity in xenograft models of human testicular and bladder cancers. J. Urol., 144, 1004-1009, 1990.

14) Logothetis, C.J., Dexeus, F.H., Sella, A., Amato, R.J., Kilbourn, R.G., Finn, L. and Gutterman, J. U. : Escalated therapy for refractory urotherial tumors: Methotrexate-vinblastinedoxorubicin-cisplatin plus unglycosylated recombinant human granulocyte-macrophage colony-stimulating factor. J. Natl. Cancer Inst., 82, 667-672, 1990.

（1991年11月27日受理） 